CORRECTION OPEN

\title{
Correction: Food addiction: a valid concept?
}

\author{
Paul C. Fletcher ${ }^{1,2}$ and Paul J. Kenny ${ }^{3}$ \\ Neuropsychopharmacology (2019) 44:834; https://doi.org/10.1038/s41386-018-0288-1
}

Correction to: Neuropsychopharmacology; https://doi.org/10.1038/ s41386-018-0203-9

This article was originally published under standard licence, but has now been made available under a [CC BY 4.0] license. The PDF and HTML versions of the paper have been modified accordingly.

(i) Open Access This article is licensed under a Creative Commons Attribution 4.0 International License, which permits use, sharing, adaptation, distribution and reproduction in any medium or format, as long as you give appropriate credit to the original author(s) and the source, provide a link to the Creative Commons license, and indicate if changes were made. The images or other third party material in this article are included in the article's Creative Commons license, unless indicated otherwise in a credit line to the material. If material is not included in the article's Creative Commons license and your intended use is not permitted by statutory regulation or exceeds the permitted use, you will need to obtain permission directly from the copyright holder. To view a copy of this license, visit http://creativecommons. org/licenses/by/4.0/.

(c) The Author(s) 2018

${ }^{1}$ Department of Psychiatry, University of Cambridge, Cambridge CB2 8AH, UK; ${ }^{2}$ Cambridgeshire and Peterborough NHS Foundation Trust, Cambrdge CB21 5EF, UK and ${ }^{3}$ Department of Neuroscience, Icahn School of Medicine at Mount Sinai, New York, NY 10029, USA

Correspondence: Paul C. Fletcher (paul.kenny@mssm.edu)

Published online: 7 December 2018 